\title{
RESILIENCE OF STUDENTS AND THEIR READINESS FOR PROFESSIONAL FUNCTIONING
}

Pichurin V.V

Dnipropetrovsk National University of Railway Transport named after Academician V.Lazaryan

\begin{abstract}
Purpose: in structure of specialist's psychological readiness for professional functioning important place is taken by formation of the so-called professionally significant personality's features. Person's resilience shall be related to them as well. The purpose is to clear up the existing tendencies in respect to resilience and its components in students. Material and methods: in the research 130 students of Dnipropetrovsk National University of Railway Transport named after Academician V.Lazaryan, participated. From them 73 were boys and 57 - girls. Their age was 17-20 years old. Diagnostic of resilience level and its components (commitment, control, challenge) was conducted with the help of resilience questionnaire by S. Maddy, adapted by D. Leontyev and Ye. Rasskazova. Results: we determined indicators of resilience, characteristic for modern students. The received results permit to speak about psychological readiness of modern students for professional functioning by factor of resilience. Conclusions: 1) absolute majority of students have high indicators of resilience and indicators within standards; 2) boys and girls have statistically significant differences by factor "involvement".
\end{abstract}

Key words: resilience, commitment, control, challenge, students.

\section{Introduction}

At present, life constantly put still more difficult tasks before man. In different kinds of functioning person shall fulfill extremely complex actions, requiring maximal psychological and physical tension for successful achievement of aim. High requirements to professional functioning of modern specialist, complexity and high expenses on his (her) training with extreme conditions of labor require appropriate psychological and psych-physiological fitness.

In psychology it is considered that psychological specificities of professional functioning are conditioned by regulating influence of not separate psychic qualities and functions but by their combinations. Combination of psychological features, which is organized for fulfillment of certain functions, is called psychological system of functioning. It includes: motives, aims, programs and informational basis of functioning; taking decision, professionally important features. Insufficient formation of separate elements of functioning's psychological system; their inadequacy to peculiarities and requirements of certain professional functioning can be a reason of reduction of professional fitness. Formation of such students' features is an important task of higher school.

In formation of psychological system of functioning special place is assigned by specialists to the so-called professionally significant features of personality. They are regarded as internal psychological characteristics of a subject, in which external specific influences of labor process reflect and which exist in the form of professional requirements to a personality. In our opinion resilience shall be related to such features.

Psychology studies a number of personality's characteristics, which facilitate person's self-realization, adaptation to professional environment, ability to overcome difficulties of life (resilience, adaptive abilities, psychological stability, personal potential and so on). Resilience is regarded as system of believes about own self, about world, about correlation with the world. It includes three comparatively autonomous components: commitment, control and challenge. Development level of these components and resilience in the whole prevents from internal tension in stress situations owing to hardy coping of stresses and taking them as insignificant. Commitment is determined as confidence in the fact that involvement in what goes on gives maximal chance to find something worthy and interesting of the person. It is considered that the person with developed commitment enjoy of own functioning. In the contrast to it with absence of such confidence there appears sense of rejection, feeling of own being outside of life. Control is regarded as assurance in the fact that struggle permits to influence on result of process even in case, when this influence is not an absolute one and success is not guaranteed. The opposite is sense of own helplessness. Person with sufficiently developed component of control feels that he himself chooses own functioning and way. Challenge is regarded as human confidence in the fact that everything happening to him (her) facilitates his (her) progressing owing to knowledge, acquired from experience. With it, it is not important, what experience is - positive or negative. Person, who regards his life as mean of acquiring experience, is ready to act even under absence of reliable guaranties of success, to his own. He considers strive for simple

(c) Pichurin V.V., 2015

http://dx.doi.org/10.15561/20755279.2015.0305 
comfort and safety as factor, which makes life poorer. In the base of challenge there is idea of progressing through active mastering of knowledge and experience with their following usage.

Problem of resilience was the subject of scientific researches of foreign and domestic specialists D. Koshaba, S. Maddy, D. Leontyev, L. Alexandrova, L. Dikaya et al. It should be noted also such works as: [2 - 4, 9 - 20] and many other. и многие другие. Researches of resilience in psychology were conducted by such directions as connection of 5resilience and other characteristics of personality, with clinical and behavioral variables (health, effectiveness of fulfillment and etc.) Problems of development of resilience were also studied. Among the latter, domestic we can note the works by K. Mannapova [1], who regarded resilience in system of conception "vitality". Also we can mention the work by S. Babatina, who researched interconnection of resilience with temporal characteristics of student's personality [6].

The conducted analysis of all mentioned works shows that in spite of significant progress, development of modern students' resilience still is remaining and urgent problem as well as usage of physical culture and sport functioning for this purpose. One of tasks, which (in the author's opinion) can be effectively solved in the frames of psychological and psycho-physiological training at physical culture classes [5, 7], is training of students' resilience. With planning of work on resilience formation as well as its components it is necessary to clearly know existing tendencies in this sphere as well as peculiarities of boys and girls' resilience.

Purpose, tasks of the work, material and methods

The purpose of the work is to clear up the existing tendencies in respect to resilience and its components in students.

The tasks of the research:

1. Determine the level of students' resilience and such its components as commitment, control and challenge.

2. State presence or absence of statistically significant differences between boys and girls in respect to their resilience and its components.

In the research 130 students of Dnipropetrovsk National University of Railway Transport named after Academician V.Lazaryan, participated. From them 73 were boys and 57 - girls. Their age was 17-20 years old. Sample was formed with random sampling.

Diagnostic of resilience level and its components (involvement, control, taking of risk) was conducted with the help of resilience questionnaire by S. Maddy, adapted by D. Leontyev and Ye. Rasskazova. From statistical methods we used t-criterion of Student for independent samples.

Results of the research

We found the following: indicators, characterizing students by factor "commitment" are given in table 1 .

Table 1.

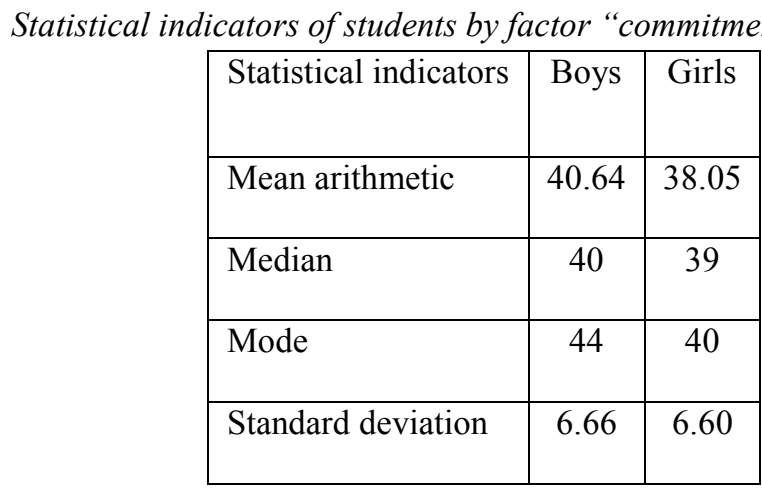

In boys' group $(\mathrm{N}=73)$ low indicators by this factor was found in 4 students and was $5.5 \%$. In girls' group ( $\mathrm{N}$ $=57)$ indicators of such level were registered in 8 girl-students $(14 \%)$. Indicators within standard were registered in 49 boys (67\%) and 43 girls (75.5\%). High indicators were diagnosed in 20 boys (27.5\%) and in 6 girls (10.5\%).

Indicators by factor "control" are given in table 2 . 


Statistical indicators of students by factor "control"
\begin{tabular}{|l|c|c|}
\hline Statistical indicators & Boys & Girls \\
\cline { 2 - 4 } & & \\
\hline Mean arithmetic & 34.11 & 32.56 \\
\hline Modian & 34 & 32 \\
\hline Standard deviation & 6.86 & 6.25 \\
\hline
\end{tabular}

Table 2 .

By this factor low indicators were demonstrated by 2 boys (3\%) and 2 girls (3.5\%). Indicators within standards were registered in 50 boys (68\%) and 40 girls (70\%).High indicators were detected in 21 boys (29\%) and in 15 girls $(26.5 \%)$.

The students' indicators by factor "challenge" are presented in table 3.

Table 3 .

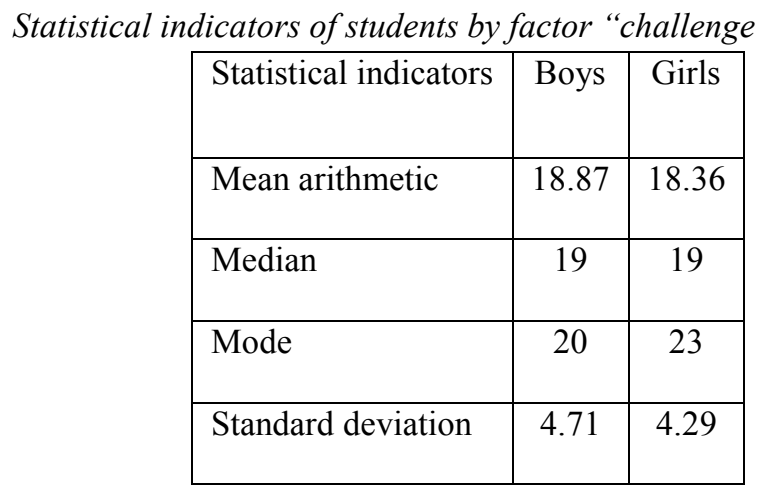

Distribution by this factor was as follows: low indicators were diagnosed in 2 girls $(3.5 \%)$. In boys' group there were no indicators of such level. Indicators within standards were registered in 35 boys (48\%) and in 26 girls (45.5\%). High indicators by this factor were found in 38 boys (52\%) and in 29 girls (51\%).

Students' indicators by total mark of resilience are given in table 4.

Statistical indicators of students by total mark of resilience $(N=130)$

Table 3.

\begin{tabular}{|l|c|c|}
\hline Statistical indicators & Boys & Girls \\
\hline Mean arithmetic & 93.63 & 88.98 \\
\hline Median & 93 & 92 \\
\hline Mode & 98 & 99 \\
\hline Standard deviation & 15.59 & 14.20 \\
\hline
\end{tabular}

By this indicator low level was found in 3 boys (4\%) and in 2 girls (3.5\%). Indicators within standards were found in 47 boys (64.5\%) and in 41 girls (72\%). Indicators of high level were registered in 23 boys (31,5\%) and in 14 girls $(24.5 \%)$.

Secondary statistical processing of the received data was carried out with the help of Student's t0criteruion for independent samples. We compared boys' group with girls' one by indicators of commitment, control, challenge and 
resilience. Statistically zero hypothesis was the assumption that confidence of differences between resilience indicators (commitment, control and challenge) of boys and girls' groups does not differ significantly from zero. Alternative statistical hypothesis was assumption that confidence of differences between resilience indicators (commitment, control and challenge) of boys and girls' groups significantly differs from zero.

We have established:

a) indicators, which are in zone of insignificance ((commitment, control and challenge).

b) Statistically significant result (at level of statistical significance 0.05 ) by factor "commitment". Boys' indicators by this factor turned out to be statistically much higher.

On the base of the a.m.:

a) we made conclusion about validity of zero hypothesisc in respect to confidence of differences between indicators of boys' group and girls' group by such criteria as "control", "challenge" and "resilience";

б) in respect to confidence of differences between indicators of boys' group and girls' group by such criterion as "commitment" zero hypothesis was rejected.

\section{Discussion}

When planning experiment we based on the fact that modern professional activity often is accompanied by significant emotional tension. It negatively influences on specialists' workability, results in condition of their health. In psychology resilience is regarded as personal characteristic, which facilitates adaptation to professional environment, ability to overcome life difficulties; i.e. it is a professionally significant characteristic. In previous researches [8] we registered low level of students' psychological and psycho-physiological readiness for professional functioning by a number of professionally significant indicators. A question about students' psychological readiness for labor by resilience factor appeared.

Results of our research of students' resilience show that absolute majority of students have high indicators and indicators within standards. For example by factor "commitment" quantity of such students was $94.5 \%$ in group of boy students and $86 \%$ ion girls' group. By factor "control" such students were $97 \%$ in boys' group and $96.5 \%$ in girls' group. By factor "challenge" quantity of such students was $100 \%$ in group of boys and $96.5 \%$ in girls' group. By general indicator of resilience quantity of such students was $96 \%$ in boys group and $96.5 \%$ in girls' group. The received results permit to say that most of students are ready to overcome life obstacles and professional difficulties. In situations of increased emotional tension they also are bent to take reasonable decisions and continue active functioning. In our opinion the received results permit to say about psychological fitness of modern students to professional functioning by factor "resilience".

When comparing boys and girls' groups we did not find any statistically significant differences by factors "control" and "challenge" and by general indicator of resilience. At the same time we registered statistically significant differences between indicators by factor "commitment" (boys' indicators are higher). For explanation of this fact it is purposeful to carry out special psychological research.

\section{Conclusions:}

Formulating main conclusions we can note the following:

1. Absolute majority of students have high indicators of resilience and indicators within standards.

2. There are statistically significant differences between boys ands girls by factor "commitment". Indicators of boys are much higher.

The prospects of further researches we connect with studying of sport and physical culture functioning's usage for training of students' resilience.

\section{Acknowledgement}

The author acknowledges senior teacher of physical education department of Dnipropetrovsk National University of Railway Transport named after Academician V.Lazaryan Mrs. Lutayeva Nadezhda Valentinovna for her assistance in organization of girls' group testing.

The work has been fulfilled in compliance with topical plan of scientific research works of physical education department of Dnipropetrovsk National University of Railway Transport named after Academician V.Lazaryan. It is also a component of topic "Theoretical-methodological and pedagogic principles of students' psychological and psycho-physiological training in process of physical education" (state registration number 0113U006237). 


\section{Conflict of interests}

The author declares that there is no conflict of interests.

\section{References:}

1. Mannapova KR. Zhittiestijkist' v sistemi poniattia zhittiezdatnosti [Resilience in system of conception of vitality]. Psikhologiia 2012;44(1):143-150. (in Ukrainian)

2. Aleksandrova LA. K koncepcii zhiznestojkosti $v$ psikhologii [On conception of resilience in psychology]. Sibirskaia psikhologiia segodnia 2004;2:82-90. (in Russian)

3. Leont'ev DA, Rasskazova EI. Test zhiznestojkosti [Test of resilience], Moscow: Meaning; 2006 (in Russian)

4. Leont'ev DA. Lichnostnyj potencial: struktura $i$ diagnostika [Personal potential: structure and diagnostic], Moscow: Meaning; 2011 (in Russian)

5. Pichurin VV. Osnovi organizacii psikhologichnoi i psikhofizichnoi pidgotovki studentiv zaliznichnikh vuziv v procesi fizichnogo vikhovannia [Principles of organization of psychological and psycho-physical training of railway higher educational establishments' students in process of physical education]. Fizichne vikhovannia $i$ sport 2012;26:84-90. (in Ukrainian)

6. Babatina SI. Osoblivosti vzaiemozv'iazku zhittiestijkosti z temporal'nimi kharakteristikami osobistosti studenta [Peculiarities of interconnection of resilience with temporal characteristics of student's personalities]. Aktual'ni problemi derzhavnogo upravlinnia, pedagogiki ta psikhologii 2012;1(6):437-441. (in Ukrainian)

7. Pichurin VV. Psychological and psycho-physical training as a part of physical education of students in higher educational establishments. Pedagogics, psychology, medical-biological problems of physical training and sports 2014;11:44-48. http://dx.doi.org/10.15561/18189172.2014.1108

8. Pichurin VV. Psikhologichna i psikhofizichna gotovnist' studentiv-zaliznichnikiv do profesijnoi praci [Psychological and psycho-physical fitness of railway students for professional functioning]. Fizichne vikhovannia i sport 2013;37:95-103. (in Ukrainian)

9. Bartone PT. Resilience under military operational stress: can leaders influence hardiness? Military psychology 2006;18:131-148. http://dx.doi.org/10.1207/s15327876mp1803s_10.

10. Eid J, Morgan CA. Dissociation, hardiness, and performance in military cadets participating in survival training. Military medicine 2006;171;5:436-442.

11. Hystad SW, Eid J, Laberg JC, Johnsen B, Bartone PT. Academic stress and health: exploring the moderating role of personality hardiness. Scandinavian journal of educational research 2009;53(5):421-429. http://dx.doi.org/10.1080/00313830903180349.

12. Klag S, Bradley G. The role of hardiness in stress and illness: an exploration of the effect of negative affectivity and gender. British journal of health psychology 2004;9;2:137-161. http://dx.doi.org/10.1348/135910704773891014.

13. Kobasa SC, Maddi SR, Puccetti MC, Zola MA. Effectiveness of hardiness, exercise and social support as resources against illness. Journal of psychosomatic research 1985;29(5):525-533. http://dx.doi.org/10.1016/0022-3999(85)90086-8.

14. Kobasa SC, Maddi SR, Kahn S. Hardiness and health: a prospective study. Journal of personality and social psychology 1982;42(1):168-177. http://dx.doi.org/10.1037/0022-3514.1.168.

15. Kobasa SC, Maddi SR, Zola MA. Type A and hardiness. Journal of behavioral medicine 1983;6(1):41-51. http://dx.doi.org/10.1007/BF00845275.

16. Maddi SR. Hardiness: an operationalization of existential courage. Journal of humanistic psychology 2004;44(3):279-298. http://dx.doi.org/10.1177/0022167804266101.

17. Maddi SR. Hardiness: the courage to grow from stresses. Journal of positive psychology 2006;1(3):160-168. http://dx.doi.org/10.1080/17439760600619609.

18. Pengilly JW, Dowd ET. Hardiness and social support as moderators of stress. Journal of clinical psychology. 2000;56(6):813-820. http://dx.doi.org/10.1002/(SICI)1097-4679(200006)56:6<813::AID-JCLP10>3.0CO;2-Q

19. Sinclair RR, Tetrick LE. Implications of item wording for hardiness structure, relations with neuroticism, and stress buffering. Journal of research in personality 2000;34(1):1-25. http://dx.doi.org/10.1006/jrpe.1999.2265. 
20. Soderstrom M, Dolbier C, Leiferman J, Steinhardt M. The relationship of hardiness, coping strategies, and perceived stress to symptoms of illness. Journal of behavioral medicine 2000;23(3):311-328. http://dx.doi.org/10.1023/A:1005514310142.

\section{Information about the author:}

Pichurin $\quad$ V.V.: $\quad$ http://orcid.org/0000-0002-3893-375X; valeriypichurin@gmail.com; Dnipropetrovsk National University of Railway Transport named after Academician V.Lazaryan; St. Lazaryana, 2, Dnipropetrovsk, 49010, Ukraine.

Cite this article as: Pichurin V.V. Resilience of students and their readiness for professional functioning. Physical education of students 2015;3:38-43. http://dx.doi.org/10.15561/20755279.2015.0305

The electronic version of this article is the complete one and can be found online at: http://www.sportpedu.org.ua/html/arhive-e.html

This is an Open Access article distributed under the terms of the Creative Commons Attribution License, which permits unrestricted use, distribution, and reproduction in any medium, provided the original work is properly cited (http://creativecommons.org/licenses/by/3.0/deed.en).

Received: 16.06 .2015

Accepted: 29.06.2015; Published: 30.06.2015 